Information for citation:

Khudolej K. M. Nuzhen li konstituzionnyj (ustavnyj) sud v sub"ekte RF? [Do Federal Subjects of Russia Need Constitutional (Statutory) Courts?]. Vestnik Permskogo Universiteta. Juridicheskie Nauki - Perm University Herald. Juridical Sciences. 2016. Issue 34. Pp. 391-401. (In Russ.). DOI: 10.17072/1995-4190-2016-34-391-401.

UDC 342.565 .2

DOI: 10.17072/1995-4190-2016-34-391-401

\title{
DO FEDERAL SUBJECTS OF RUSSIA NEED CONSTITUTIONAL (STATUTORY) COURTS?
}

\author{
K. M. Khudoley \\ Perm State University \\ 15, Bukireva st., Perm, 614990, Russia \\ ORCID: 0000-0003-1805-0674 \\ ResearcherID: E-3186-2016 \\ Articles in DB «Scopus» / «Web of Science»: \\ DOI: $10.17072 / 1995-4190-2016-33-258-267$ \\ e-mail: kostya-hudoley@yandex.ru
}

Introduction: the article considers questions of the establishment of constitutional (statutory) courts in federal subjects of the Russian Federation and the possibility for other public authorities to exercise their powers. Purpose: to analyze provisions of the federal and regional legislation on constitutional (statutory) courts, statistics reflecting the efficiency of their activity and the necessity to establish these institutions in federal subjects of the Russian Federation. Methods: the methodological framework of the research is based on a set of scientific methods, including the dialectic method and general scientific methods of cognition (analysis, synthesis, induction and deduction). Specific scientific methods of cognition (legalistic, comparative and legal) were also used. Special attention was paid to the comparative and system methods of research. Results: constitutional (statutory) courts, acting as subsidiary bodies of the constitutional control, in many respects provide efficiency of other human rights and supervisory bodies (the Commissioner for Human Rights in a subject of the Russian Federation, the Prosecution Service). Therefore, they are indispensable for the protection of the constitutional system, rights and freedoms of citizens, settlement of disputes between authorities within a system of "checks and balances". Conclusions: powers of constitutional (statutory) courts to implement specialized constitutional (statutory) supervision are exclusive and irreplaceable. It is impossible for any judicial or non-judicial authorities to equally substitute the constitutional (statutory) court of a federal subject of the Russian Federation for another body (except for the Constitutional Court of the Russian Federation in case such powers were delegated in accordance with Article 11 of the Constitution of the Russian Federation by means of agreements on the differentiation of areas of jurisdiction and powers between public authorities of the Russian Federation and public authorities of federal subjects of the Russian Federation).

Keywords: constitutional (statutory) courts; constitutional court; constitutional justice; right to address; public authorities of a federal subject of the Russian Federation; local government bodies; establishment; elimination

\section{Information in Russian}

\section{НУЖЕН ЛИ КОНСТИТУЦИОННЫЙ (УСТАВНЫЙ) СУД В СУБЫЕКТЕ РФ?}

\section{К. М. Худолей}

Кандидат юридических наук, доцент кафедры конституционного и финансового права Пермский государственный национальный исследовательский университет 614990, Россия, г. Пермь, ул. Букирева, 15

(C) Khudoley K. M., 2016 
ORCID: 0000-0003-1805-0674

ResearcherID: E-3186-2016

Статьи в БД «Scopus» / «Web of Science»:

DOI: $10.17072 / 1995-4190-2016-33-258-267$

e-mail: kostya-hudoley@yandex.ru

Введение: в статье анализируются вопросы учреждения конституционного (уставного) суда субъекта РФ и возможности осуществления его полномочий иными органами государственной власти. Цель: рассмотреть положения федерального и регионального законодательства о конституционных (уставных) судах и статистику, отражающую эффективность их деятельности, и обосновать необходимость учреждения данных органов в субъектах РФ. Методы: методологическую основу исследования составляют совокупность методов научного познания, в том числе диалектический метод, и общенаучные методы познания (анализ, синтез, индукиия и дедукиия). Автором широко использовались также частнонаучные методы познания (формально-юридчческий, сравнительно-правовой). В ходе научного поиска особое внимание уделялось сравнительному, системному методам исследования. Результаты: конституциионные (уставные) суды, будучи субсидиарными органами конституционного контроля, во многом обеспечивают эффективность иных правозащитных и контрольных органов (уполномоченного по правам человека в субъекте РФ, прокуратуры) и поэтому являются незаменимыми органами в части охраны конституционного строя, защиты прав и свобод граждан, разрешения споров между органами власти в рамках системы «сдержек и противовесов». Выводы: полномочия конституционных (уставных) судов по осущзествлению специализированного конституционного (уставного) контроля относятся к числу эксклюзивных и невосполнимых. Равноценно заменить конституц̧ионный (уставный) суд субъекта РФ другим органом (за исключением Конституциионного Суда РФ в случае, если такие полномочия были переданы посредством заключенных в соответствии со ст. 11 Конституциии РФ договоров о разграничении предметов ведения и полномочий между органами государственной власти РФ и органами государственной власти субъектов РФ) не представляется возможным никакими судебными или несудебными органами.

Ключевые слова: конституционные (уставные) суды; конституционный суд; конституционное правосудие; право на обращение; органы государственной власти субъекта РФ; органы местного самоуправления; учреждение; ликвидация

\section{Introduction}

In modern Russia constitutional (statutory) courts are considered by the regional power to be an absolutely alien and unnecessary element of the state mechanism, as is evident from unwillingness in a number of regions to renominate their judges (St. Petersburg, Buryatia), elimination of some of them (Mordovia, Chelyabinsk region), mass cancellation of laws on bodies of the constitutional (statutory) justice (Samara and Kurgan, Krasnoyarsk and Stavropol regions) or abeyance of their action (Tyumen region). Therefore, it is not surprising that though the Basic Laws of 50 subjects of the Russian Federation provide the opportunity to create constitutional (statutory) courts, and in 23 of the subjects relevant laws have been adopted, they only act in 16 regions (the powers of the Constitutional Court of the Re- public of Buryatia were blocked by the regional parliament after renewal of action of the law on this court in 2016; in Moscow, the Irkutsk region, Karachay-Cherkessia, Khanty-Mansi Autonomous Area judges are still not appointed, and the law of the Moscow region on the statutory court of 2006 has not come into force).

The establishment of constitutional (statutory) courts in subjects of the Russian Federation testifies to judicial federalism, characterized by the features of "centralization" and "decentralization". According to foreign scientists, "centralization" involves requirements of the state integrity (formation of the basis of the judicial system at the federal level, adoption of uniform rules of legal proceedings) $[13$, p. $16 ; 14$, p. $412 ; 16$, p. $160 ; 17$, p. 394; 21]. They attribute manifestations of "decentralization" to existence of the two-level 
system of judicial authorities, the constitutional differentiation of areas of jurisdiction, application of the regional legislation by courts, formation of judicial authorities by regional authorities of subjects or directly the population of a subject of the federation. However, the judicial federalism does not always involve the creation of their own bodies of the constitutional control by subjects of the federation. In the USA, besides federal courts of the general jurisdiction led by the Supreme Court of the United States, the bodies executing the constitutional control also include courts of states which also exercise in full the granted right to interpret federal laws and to declare them invalid in case of contradiction to the Constitution of the USA [20, p. 92]. In all states of Germany, except one, constitutional (state) courts which, in the same way as in Russia, do not form a uniform system with the federal constitutional court are created. In the Swiss Confederation, the constitutional control at the regional level is only exercised in 3 subjects: in the canton of Basel-Land - administrative courts, in Nidwalden - the Supreme Court of the canton, in the canton Jura - the Constitutional Court of the canton. In Argentina, only in the Province of Tucuman the Constitutional Court which realizes functions of the constitutional control along with federal courts of general jurisdiction was created. In other federations, the constitutional control is only exercised at the federal level.

\section{Performance Indicators of the Constitutional (Statutory) Courts of Subjects of the Russian Federation}

The constitutional court of the Russian Federation in the definition of March 3, 2015 No. 421-O ${ }^{1}$ specified that the solution of the question of the creation of the constitutional (statutory) court as a

\footnotetext{
${ }^{1}$ At the request of a group of deputies of the State Duma about examination of constitutionality of clause 2 of part 1 of article 1 of the Law of the Republic of Buryatia "On suspension and repeal of some legislative acts of the Republic of Buryatia in connection with adoption of law of the Republic of Buryatia "On the republican budget for 2015 and for the planning period of 2016 and 2017"'?: Determination of the Constitutional Court of the Russian Federation of 03.03.2015 No. 421-O [Electronic resource]. Access from the system "ConsultantPlus.
}

subsidiary body of the constitutional control is under authority of subjects of the Russian Federation. Thus, the subject of the Russian Federation has to consider not only the financial opportunities causing need for reduction of account obligations (among them for the account of expenses on ensuring the activity of the constitutional (statutory) court) but also other circumstances characterizing its need for a body of the constitutional control, efficiency of its activity, including number of the addresses considered by it for a certain calendar period, possibility to continue its work under other conditions and so forth. To decrease account obligations on the activity of the constitutional (statutory) courts, a number of authors even suggest using the experience of some constitutional courts of the states of Germany in which judges work at an irregular basis and earn reward only for participation in hearing of cases [7, p. 5]. Considering small load of courts, this suggestion makes sense but demands essential change in the legislation: members of constitutional (statutory) courts replace the state positions of the subject of the Russian Federation and cannot be engaged in other paid activity (including positions of the federal judge), except teaching, creative or scientific. It is obviously important to note that up to 2000 the law on the Constitutional Chamber of the Republic of Adygea and the law of Khanty-Mansi Autonomous Area on the Statutory Court of this region allowed members of these bodies of the constitutional (statutory) control to combine jobs, with 6 of 9 members of the Constitutional Chamber in Adygea working at a changeable basis. The question of creation of a "low budget" constitutional (statutory) court where judges would work at a changeable basis, was unsuccessfully raised in other regions as well (the Omsk and Samara regions). Owing to political reasons, the creation of even such "low budget constitutional (statutory) courts in regions is thought to have low chances. Results of work of the constitutional and statutory courts as of March 1, 2016 are given below in accordance with data provided at their sites. 


\begin{tabular}{|c|c|c|c|c|}
\hline Court & $\begin{array}{c}\text { Total number } \\
\text { of resolutions } \\
\text { (conclusions) made }\end{array}$ & $\begin{array}{c}\text { Number } \\
\text { of decisions made } \\
\text { in } 2015 \\
\text { (resolutions of them) }\end{array}$ & $\begin{array}{c}\text { The maximum } \\
\text { quantity of the } \\
\text { decisions made } \\
\text { (resolutions of them) } \\
\text { for a year }\end{array}$ & $\begin{array}{l}\text { The budget for } 2015 \\
\text { (the last year of work) } \\
\text { in thousands rubles } \\
\text { (per cent of the total } \\
\text { number of expenses } \\
\text { of a subject of the } \\
\text { Russian Federation) }\end{array}$ \\
\hline $\begin{array}{l}\text { CC of the Republic } \\
\text { of Adygea }\end{array}$ & $32(5)$ & $4(0)$ & 12(4) (2002) & $9,378.9(0.06 \%)$ \\
\hline $\begin{array}{l}\text { CC of the Republic } \\
\text { of Bashkortostan }\end{array}$ & 32 & $12(2)$ & $15(1)(2009)$ & $24,359(0.016 \%)$ \\
\hline $\begin{array}{l}\mathrm{CC} \text { of the Republic } \\
\text { of Buryatia }\end{array}$ & $44(2)$ & $\begin{array}{c}\text { activity was } \\
\text { suspended till } 2016\end{array}$ & $7(0)(2000)$ & $\begin{array}{c}\text { in } 2013 \\
13,758 \\
(0.026 \%)\end{array}$ \\
\hline $\begin{array}{l}\text { CC of the Republic } \\
\text { of Dagestan }\end{array}$ & 24 & $2(1)$ & $17(2)(2012)$ & $21,994.1(0.024 \%)$ \\
\hline $\begin{array}{l}\text { CC of the Republic } \\
\text { of Ingushetia }\end{array}$ & 11 & $3(1)$ & $10(3)(2013)$ & $13,626.5(0.047 \%)$ \\
\hline $\begin{array}{l}\text { CC of the Kabardino- } \\
\text { Balkar Republic }\end{array}$ & 15 & $1(1)$ & $5(2)(1999)$ & $23,758.4(0.071 \%)$ \\
\hline $\begin{array}{l}\text { CC of the Republic } \\
\text { of Karelia }\end{array}$ & 117 & $9(2)$ & $12(6)(2007)$ & $17,077.6(0.052 \%)$ \\
\hline $\begin{array}{l}\text { CC of the Komi } \\
\text { Republic }\end{array}$ & 103 & $7(4)$ & $17(13)(2011)$ & $26,197.9(0.038 \%)$ \\
\hline $\begin{array}{l}\text { CC of the Republic } \\
\text { of Mari El }\end{array}$ & 22 & $4(2)$ & $4(2)(2015)$ & $16,548(0.066 \%)$ \\
\hline $\begin{array}{l}\text { CC of the Sakha } \\
\text { Republic (Yakutia) }\end{array}$ & $132(2)$ & $11(4)$ & $14(12)(2000)$ & $60,324(0.033 \%)$ \\
\hline $\begin{array}{l}\text { CC of the Republic of } \\
\text { North Ossetia-Alania }\end{array}$ & 41 & $8(3)$ & $9(5)(2013$ г.) & $17,136.3(0.074 \%)$ \\
\hline $\begin{array}{l}\text { CC of the Republic } \\
\text { of Tatarstan }\end{array}$ & 65 & $23(5)$ & $23(5)(2015)$ & $34,590.7(0.016 \%)$ \\
\hline $\begin{array}{l}\text { CC of the Republic } \\
\text { of Tyva }\end{array}$ & 20 & no decisions & $7(6)(2004)$ & $27,214.9(0.13 \%)$ \\
\hline $\begin{array}{l}\text { CC of the Chechen } \\
\text { Republic }\end{array}$ & 1 & no decisions & $2(1)(2011)$ & $35,360.6(0.055 \%)$ \\
\hline $\begin{array}{l}\text { SC of the Kaliningrad } \\
\text { region }\end{array}$ & 78 & $80(11)$ & $80(11)(2015)$ & $19,567.6(0.032 \%)$ \\
\hline $\begin{array}{l}\text { SC of the Sverdlovsk } \\
\text { region }\end{array}$ & 111 & $7(5)$ & 29(12) (1999) & $50,087.4(0.025 \%)$ \\
\hline SC of St. Petersburg & 58 & $11(3)$ & $40(8)(2005)$ & $90,520.1(0.02 \%)$ \\
\hline $\begin{array}{l}\mathrm{SC} \text { of the Chelyabinsk } \\
\text { region }\end{array}$ & 4 & was abolished in 2014 & $12(3)(2013)$ & $\begin{array}{c}\text { in } 2014 \\
21,677(0.019 \%)\end{array}$ \\
\hline
\end{tabular}


Apparently, constitutional (statutory) courts are not luxury: their expenses make up hundredths of a percent of the general budget expenditures and are comparable to cumulative costs of activity of other regional human rights bodies (the Commissioner for Human Rights, the Ombudsman for Children, the Commissioner for Businessmen Rights). And overall performance of both regional human rights bodies and prosecutor's office directly depends on bodies of the constitutional (statutory) justice (following addresses of prosecutors they issued 40 resolutions, and those of Commissioners for Human Rights 6 resolutions). For comparison, the budget of the Constitutional Court of the Russian Federation for 2015 makes 641,089.6 thousand rubles, and of constitutional (statutory) courts - 560,163.9 thousand rubles. Thus, for 2015 the Constitutional Court of the Russian Federation issued 34 resolutions and 3025 determinations, and bodies of the constitutional (statutory) justice -44 resolutions and 138 determinations: the "cost" of consideration of one matter in the constitutional (statutory) courts of subjects of the Russian Federation several times exceeds the similar indicator in the federal constitutional court.

During the whole period, regional bodies of the constitutional justice considered over 1.6 thousand cases, on which more than 900 resolutions were adopted. Thus, during the first years of the work of constitutional (statutory) courts, their activity was comparable with that observed in constitutional courts of the states of Germany. In 1969-1970, regional bodies of the constitutional justice of the lands of Germany were regarded as excessive institutions, as in case with Russia [21, p. 78]. However, then the number of cases considered by constitutional (statutory) courts in some regions decreased (over the last 5 years the constitutional courts of Chechnya, Kabardino-Balkaria, Tyva, Adygea adopted only one resolution each).

Meanwhile, it is necessary to emphasize that constitutional (statutory) courts have no right to consider cases on their own initiative. The small number of appeals to courts can be explained by the fact that they are quite often perceived as a sinecure for representatives who are loyal to the regional elite or as a tribute to attributes of statehood of subjects of the federation, thus many constitutional and legal problems in regions are not noticed or resolved in a different way. Activity of the most ef- fective constitutional (statutory) courts is not much less than that of the courts of general jurisdiction considering cases in a compliance assessment order. For comparison, in 2015 the Ulyanovsk regional court considered 10 cases on contest of regulations. At the same time, cases belonging to the constitutional (statutory) control by their nature are much more difficult than cases considered within compliance assessment by courts of general jurisdiction and demand longer and laborious work.

Legal positions of bodies of the constitutional (statutory) control are of fundamentally different quality than legal provisions contained in decisions of the courts of general jurisdiction have. As V. D. Zorkin notes, it is expressed in the fact that "the legal positions are of the obligatory character (both for the legislator and for the law enforcer) and possess a quality of the regulator of a certain type of public relations..., possess certain internal properties because they act as a standard basis in legal system and also serve as a reference point in lawmaking and law enforcement" [5, p. 119].

N. S. Bondar specifies that by means of legal positions of the constitutional court the constitutional straightening of norms which are not disqualified is provided, their uncertainty is overcome by means of specification, updating of the semantic contents of the law, collisions between precepts of law are eliminated by search for balance of the constitutional values containing in them, system hierarchical links between norms come to light, and their contents is updated [1].

The different nature of solutions of constitutional (statutory) courts and courts of general jurisdiction was repeatedly noted by bodies of the constitutional (statutory) justice. For example, in the Resolution of the Constitutional Court of the Republic of Bashkortostan of November 26, 1998. No. 8-P $\mathrm{P}^{1}$ it is specified that decisions of the Constitutional Court of the Republic of Bashkortostan, as a result of which unconstitutional regulations lose validity, have the same coverage in time, space and circle of persons as decisions of the rule-making body, and, therefore, the same general meaning as regulations, which is not inherent to acts of courts of general jurisdiction,

\footnotetext{
${ }^{1}$ On the case of interpretation of particular provisions of article 132 and article 135 of the Constitution of the Republic of Bashkortostan: Resolution of the Constitutional Court of the Republic of Bashkortostan of 26.11.1998 No. 8-P // News of Bashkortostan. 1998. December 3.
} 
being law-enforcement by their nature. Decisions of the courts of general jurisdiction, including the $\mathrm{Su}-$ preme Court of the Republic of Bashkortostan, do not possess such validity and cannot be recognized as adequate means of depriving regulations of validity in connection with their illegality.

Therefore, it is necessary to agree that lack of the constitutional (statutory) courts in each particular subject of the Russian Federation breaks the constitutional principle of the equality before the court, irrespective of residence [2, p. 274].

\section{Possibility for Implementation of Powers of Constitutional (Statutory Courts) by Other Public Authorities}

In Determination of the Constitutional Court of the Russian Federation of March 6, 2003 No. 103$\mathrm{O}^{1}$ it is stipulated that the list of questions contained in Pt. 1 Art. 27 of the Federal Constitutional Law "On the Judicial System of the Russian Federation" for consideration of which the constitutional (statutory) courts can be created cannot be considered closed. Therefore, besides interpretation of the constitution (statute) of a subject of the Russian Federation, check of compliance of the law of the subject of the Russian Federation, regulations of public authorities of the subject of the Russian Federation, local governments of the subject of the Russian Federation with the constitution (statute) of the subject of the Russian Federation, these courts resolve disputes on competence, exercise preventive control of the questions submitted for a referendum, consider draft laws on changing the Basic Law of the subject of the Russian Federation and execute some other powers.

Compliance assessment is carried out not only by constitutional (statutory) courts but also by the Constitutional Court of the Russian Federation and courts of general jurisdiction. Thus, courts of general jurisdiction are entitled to check regulations regarding compliance with other regulations having considerable validity, while the Constitutional Court of the Russian Federation - with the Constitution of the Russian Federation. However, differentiation of competence between these courts is so subtle that creates an opportunity of verifying some regulations at once in several jurisdictional bodies. It concerns, first of all, regulations of public author-

\footnotetext{
${ }^{1}$ At the request of the State Assembly of the Republic of Bashkortostan and the State Council of the Republic of Tatarstan for examination of constitutionality of part 1 of article 27 of the Federal Constitutional Law "On the Judicial System of the Russian Federation": Determination of the Constitutional Court of the Russian Federation of 06.032003 No. 103-O // Collected Legislation of the Russian Federation. 2003. No. 17. Art. 1658.
}

ities of subjects of the Russian Federation adopted on issues of joint competence of Russia and its subjects as far as norms of many of the regulations of subjects of the Russian Federation duplicate provisions of the federal legislation. But even from this perspective the creation of a constitutional (statutory) court in a subject of the Russian Federation increases the level of the constitutional legality in the region and promotes higher protection for constitutional rights and freedoms of citizens.

During a short period of time, constitutions (statutes) of some subjects of the Russian Federation transferred functions of the constitutional control to courts of general jurisdiction operating in the region (Kalmykia, Ingushetia, the Moscow region). Such practice even found understanding in legal community, though it contradicts the Cl. "o" of Art. 71 of the Constitution of Russia. Implementation of the constitutional (statutory) compliance assessment by courts of general jurisdiction in the subjects of the Russian Federation where constitutional (statutory) courts are not created is only allowed for realization of the right to judicial protection guaranteed by $\mathrm{Cl} .1$ of Art. 46 of the Constitution of the Russian Federation $(\mathrm{Cl} .1$ of the Resolution of the Plenum of the Supreme Court of the Russian Federation of November 29, 2007 No. 48 "On practice of consideration by courts of cases of contest of regulations completely or in part" ${ }^{\prime 2}$. Thus, considering provisions of the procedural legislation, it is possible to come to a conclusion that courts of general jurisdiction will consider cases under administrative but not constitutional legal procedure (Cl. 5 Art. 208 of the CAP of the Russian Federation ${ }^{3}$ ). Excluded from objects of the compliance assessment, which is carried out as administrative legal proceedings, are contracts and agreements of subjects of the Russian Federation whose constitutionality is checked according to the legislation and is carried out by separate constitutional (statutory) courts (Adygea, Chechnya, Tyva, Kabardino-Balkaria, Sakha (Yakutia), Ingushetia, the Sverdlovsk region), even though they issued only one resolution on such affairs. Moreover, the Constitutional Court of the Republic of Sakha (Yakutia) has the right to check law-enforcement practice (issued 3 resolutions), which also expands

\footnotetext{
${ }^{2}$ About practice of consideration by courts of cases of contest of regulations completely or in part: Resolution of the Plenum of the Supreme Court of the Russian Federation of 29.11.2007 (as revised of 09.02.2012) No. 48 // Bulletin of the Supreme Court of the Russian Federation. 2008. No. 1.

${ }^{3}$ Code of administrative legal proceedings of the Russian Federation: Federal law of 08.03.2015 (as revised of 29.06.2015) No. 21-FZ // Collected Legislation of the Russian Federation. 2015. No. 10. Art. 1391.
} 
an object of the constitutional control in comparison with administrative legal proceedings.

Powers of constitutional (statutory) courts in full on compliance assessment, settlement of disputes about competence, etc. in the subjects of the Russian Federation where these bodies have not been created can be carried out by the Constitutional Court of the Russian Federation provided they were transferred by contracts signed according to Art. 11 of the Constitution of the Russian Federation concerning differentiation of areas of jurisdiction and powers between public authorities of the Russian Federation and public authorities of subjects of the Russian Federation (Cl. 7 Pt. 1 Art. 3 of the Federal Constitutional Law "On the Constitutional Court of the Russian Federation"1). This situation acts as an analogue to the norm stipulated in Art. 99 of the Basic Law of the Federal Republic of Germany, which provides that the law can grant the Federal Constitutional Court the right to consider constitutional disputes within one land concerning application of its right. Powers on the constitutional control in the State of Schleswig-Holstein are assigned to the federal constitutional court: the land is small both in size of its territory and population, and till 1990 it had a statute not a constitution.

Assignment of functions of the constitutional (statutory) court to the Constitutional Court of the Russian Federation in case a body of the constitutional (statutory) justice is not created in the subject of the Russian Federation is more preferable than implementation of compliance assessment by courts of general jurisdiction. Judges of the Constitutional Court of the Russian Federation specialize in hearing of cases within the constitutional but not general compliance assessment and therefore understand a constitutional and legal matter better. As is noted by foreign scholars, even in countries using "the American model" of the constitutional control exercised by courts of general jurisdiction not all judges are capable of assessing constitutionality of regulations professionally [12, p. $148 ; 15$, p. 8]. Furthermore, a constitutional trial in the federal constitutional court bears much resemblance to that taking place in regional constitutional (statutory) courts.

Another noteworthy question of special interest is as follows: what body will exercise the constitutional control after abolition of the constitutional (statutory) court in the subject of the Russian Federation? According to p. 3 of Art. 17 of the Federal Constitutional Law "On the Judicial System of the

\footnotetext{
${ }^{1}$ On the Constitutional Court of the Russian Federation: Federal constitutional law of 21.07.1994 No. 1-FKZ (as revised of 14.12.2015) // Collected Legislation of the Russian Federation. 1994. No. 13. Art. 1447.
}

Russian Federation"2 any court cannot be abolished if the matters of implementation of justice carried to its maintaining were not referred to in jurisdiction of another court at the same time. The subject of the Russian Federation has no right to delegate power of a constitutional (statutory) court to a court of general jurisdiction owing to reference of questions of the judicial system to questions of maintaining the federal center. As an exception, the federal legislation allows courts of general jurisdiction to implement only powers on compliance assessment of all competence of bodies of the constitutional (statutory) justice. In our opinion, in case of abolition of a constitutional (statutory) court in a subject of the Russian Federation its powers are to be delegated without fail to the Constitutional Court of the Russian Federation under a contract concluded between public authorities of the Russian Federation and the subject of the Russian Federation. Therefore, the precedent which happened in the Chelyabinsk region where powers of the abolished Statutory Court were not delegated to any judicial body looks strange.

Difference of the constitutional legal proceedings from administrative ones is expressed in particular in the fact that in the legislation of the majority of subjects of the Russian Federation (except Bashkortostan, Karelia, St. Petersburg, the Kaliningrad region) the right to initiate the process on verification of a statutory act regarding its compliance with the constitution (statute) of the subject of the Russian Federation in a body of the constitutional (statutory) justice is granted not only to citizens but also courts. And courts of general jurisdiction invoke this right (following their addresses, constitutional and statutory courts issued 7 resolutions during the whole period of time). O. V. Brezhnev distinguishes three models of the legal regulation of hearing of cases in constitutional (statutory) courts following appeals of courts to bodies of regional constitutional justice within abstract, concrete, or abstract and concrete control [3, p. 32]. At the same time, according to the procedural legislation, implementation of compliance assessment in courts of general jurisdiction within administrative legal proceedings following appeals of other courts is not possible even if when considering the case such a court will come to a conclusion about illegality of the statutory act which is the subject to application.

According to the regional legislation, the right to appeal to constitutional (statutory) courts of subjects of the Russian Federation about verification of

\footnotetext{
${ }^{2}$ On the judicial system of the Russian Federation: Federal constitutional law of 31.12.1996 No. 1-FKZ (as revised of 05.02.2014) // Collected Legislation of the Russian Federation. 1997. No. 1. Art. 1.
} 
regulations is provided besides courts to other subjects to which the similar right is not granted within administrative legal proceedings in courts of general jurisdiction. For example, according to Art. 83 of the Law of the Kaliningrad region "On the Statutory Court of the Kaliningrad region" such right is given to each deputy of the regional duma, the association of municipalities of the Kaliningrad region, a group of not less than five deputies of a representative body of the local government, Notarial chamber of the Kaliningrad region in connection with a legal matter arisen in notarial activity. In particular, only following addresses of certain deputies, constitutional (statutory) courts issued 86 resolutions on cases of verification of regulations.

The second important power of constitutional (statutory) courts is interpretation of constitutions (statutes) of subjects of the Russian Federation. However, the number of decisions taken on this category of affairs decreases every year for objective reasons. As A. V. Mazurov notes, "the more time passes from adoption of the Constitution, the less the probability of adoption of a resolution of the Constitutional Court on interpretation of its provisions is. The legal space is gradually filled with legislative acts containing the interpretation of the Constitution and also decisions of the Constitutional Court on other categories of affairs which also contain interpretation of the Constitution and become known to the bodies entitled to interpret the Constitution" [8, p. 254]. No wonder that during the period 20112015 only 10 resolutions on cases of interpretation of constitutions (statutes) of subjects of the Russian Federation were adopted though at the initial stage of activity of constitutional (statutory) courts interpretation of Basic Laws of subjects of the Russian Federation was carried out much more often (during the whole period of time 112 resolutions have been adopted). Interpretation of Basic Laws of subjects of the Russian Federation in the regions where bodies of the constitutional (statutory) justice are not created is carried out by regional legislatures.

On the other hand, N. S. Malyutin insists on pertaining the powers for official interpretation of constitutions (statutes) of subjects of the Russian Federation to the regional legislature [9, p. 15] since the majority of constitutions of the subjects are adopted and amended by regional parliaments. However, it is necessary to agree that recording the principle of division of the powers and the "checks

\footnotetext{
${ }^{1}$ On the Statutory Court of the Kaliningrad region: Law of the Kaliningrad region of 02.10 .2000 (as revised of 02.12.2015) No. 247 Electronic resource]. Access from the system "ConsultantPlus.
}

and balances" system in the bases of the constitutional system causes need for implementation of interpretation of the constitution (statute) of the subject of the Russian Federation by a body of the constitutional (statutory) control but not the parliament. It is noteworthy that all three bills of abolition of the Statutory court of St. Petersburg which were rejected in 2009 provided transfer of power on interpretation of the Statute of this subject of the Russian Federation to jurisdiction of the Legislative Assembly of St. Petersburg. As A. V. Savoskin and O. A. Kazantsev note, in two conclusions to bills of the Legal department of the Legislative Assembly the formulation about delegation of power of official interpretation of the Statute of St. Petersburg to Legislative Assembly of St. Petersburg is recognized "disputable", and in the third conclusion lawful. In our view, such norm would contradict Pt. 3 Art. 17 of the Federal Constitutional Law "On the Judicial System of the Russian Federation" [11, p. 1110]. By the way, in the Chelyabinsk region after liquidation of the Statutory Court the power of official interpretation to the Statute of this federal subject was not transferred to the region's Legislative Assembly.

Opposing implementation of authentic interpretation of the constitution (statute) of the subject of the Russian Federation, it is possible to adduce an argument of uncertainty of a legal form of an interpretative act, which still did not receive a due constitutional and legal assessment. The Resolution of the Constitutional Court of the Russian Federation of November 17, 1997 No. 17-P ${ }^{2}$ enshrines a legal position that official interpretation of federal laws can be carried out only in the same order the law was adopted, signed and published in. In some subjects of the Russian Federation, interpretation of the regional constitution (statute) is carried out in the same form the interpreted act was adopted in (the Arkhangelsk region, Krasnodar Krai, Amur region). However, in the majority of regions interpretation of Basic Laws is given by the parliament in the form of resolutions adopted in a more simplified order than the constitution (statute) of the subject of the Russian Federation

\footnotetext{
${ }^{2}$ On the case of examination of constitutionality of Resolutions of the State Duma of the Federal Assembly of the Russian Federation of July 21, 1995 No. 1090-1 GD "On some questions of application of the Federal law "On amendments to the Law of the Russian Federation «On the status of judges in the Russian Federation»"'" and of October 11, 1996 No. 682-II GD "On the order of application of clause 2 of article 855 of the Civil Code of the Russian Federation": Resolution of the Constitutional Court of the Russian Federation of 17.11.1997 No. 17-P // Collected Legislation of the Russian Federation. 1997. No. 47. Art. 5492.
} 
(the Bryansk and Kirov regions). It seems to us that the legislation of Russia's federal subjects in the future will be guided by a legal position of the Constitutional Court of the Russian Federation. In that case interpretative activity of the parliament can become unnecessary as it will not be more difficult to eliminate the arisen uncertainty in sense of provisions of the Basic Law of the subject of the Russian Federation by means of amending the text of the regional constitution (statute).

Settlement of disputes about competence is among the powers of constitutional (statutory) courts in a number of regions (Chechnya, Adygea, Northern Ossetia-Alania, Sakha (Yakutia), Tatarstan, Kabardino-Balkaria, Buryatia). However, the share of similar affairs in the general loading of constitutional (statutory) courts is small 5 resolutions and 1 conclusion have been made by the Constitutional Court of the Republic of Buryatia, and one resolution per the constitutional courts of Tatarstan and Adygea each. Moreover, as O. V. Brezhnev notes, cases on disputes about competence are considered by constitutional (statutory) courts when other means of elimination of the disagreements arisen cannot be used or their application did not result in settlement of the dispute. For this reason, realization of this power by constitutional (statutory) courts is not a steady practice: disputes on competence are often resolved by these bodies by means of abstract or concrete compliance assessment, and also by interpretation of constitutions (statutes) of subjects of the Federation [4, p. 47]. Settlement of disputes about competence cannot be carried out by courts of general jurisdiction if in the federal subject a constitutional (statutory) court was not created, and the Constitutional Court of the Russian Federation has the right to resolve disputes on competence only between the supreme bodies of the government of the subject of the Russian Federation. Therefore, the delay in formation of constitutional (statutory) courts of subjects of the Russian Federation breaks the balance of the regional authorities and hinders from realization of the "checks and balances" system for the purpose of prevention of usurpation of the government $[10$, p. 40]. Not incidentally foreign researchers note that federalism in the system of "vertical" separation of powers and constitutional justice in the system of "horizontal" separation of powers are to be regarded as an essential element of the constitutional system based on separation of powers, counteracting excessive concentration of the government [18, p. 312]. Furthermore, constitutional (statutory) courts rather rarely consider cases on check of the question submitted for a referendum (only 2 resolutions have been adopted) and cases of preliminary constitutional control of acts of the constitutional reform ( 5 conclusions by the Constitutional Court of the Republic of Adygea and also 8 resolutions by the Statutory Court of the Kaliningrad region have been made). However, the check of constitutionality of draft laws on amending the Basic Law of the subject of the Russian Federation is at the moment provided only in the legislation of Adygea, Sakha (Yakutia) and the Kaliningrad region while the check of questions submitted for a referendum - in Chechnya, Adygea and Sakha (Yakutia). If there is no a constitutional (statutory) in a subject of the Russian Federation, courts of general jurisdiction can exercise only the subsequent control of the regulations adopted on a referendum regarding their compliance with the acts of major validity. Moreover, only the subsequent but not preliminary control can be exercised by the Constitutional Court of the Russian Federation concerning laws of subjects of the Russian Federation on change of provisions of constitutions (statutes) of subjects of the Russian Federation, exclusively regarding their compliance with the federal Constitution.

Control and certifying powers conferred on the constitutional (statutory) courts in Tatarstan, Sakha (Yakutia), Kabardino-Balkaria and Northern Ossetia-Alania have also been seldom used by them (only one resolution has been adopted). However, it is necessary to emphasize that absence of a constitutional (statutory) court in a region actually excludes a possibility of application of measures of constitutional and legal responsibility to authorities in the case its realization requires establishment of legally significant facts by bodies of the constitutional (statutory) justice within the constitutional legal proceedings.

\section{Results}

Constitutional (statutory) courts, acting as subsidiary bodies of the constitutional control, in many respects provide efficiency of other human rights and control bodies (Commissioner for Human Rights in the subject of the Russian Federation, prosecutor's offices), therefore being indispensable bodies for protection of the constitutional system, 
protection of civil rights and freedoms and settlement of disputes between authorities within the "checks and balances" system both at the horizontal level (in the relations between public authorities of the subject of the Russian Federation), and at the vertical level (in the relations between the federal center and federal subjects).

\section{Conclusions}

The majority of powers of constitutional (statutory) courts concerning exercising the specialized constitutional (statutory) control belong to indispensable ones. It is impossible to equally replace a constitutional (statutory) court of a subject of the Russian Federation with activity of another judicial or non-judicial authority (except for the Constitutional Court of the Russian Federation in case such powers were delegated by contracts signed according to Art. 11 of the Constitution of the Russian Federation dealing with differentiation of the areas of jurisdiction and powers between public authorities of the Russian Federation and those of federal subjects).

\section{References}

1. Bondar' N. S. Vlast'i svoboda na vesakh konstitutsionnogo pravosudiya [The Authority and Freedom on the Scales of the Constitutional Justice]. Moscow, 2005. 592 p. (In Russ.).

2. Bondar' N. S. Konstitutsiya, Konstitutsionnyj sud $i$ nalogovoe pravo [Constitution, Constitutional Court and Tax Law]. Nalogi - Taxes. 2006. Issue 3. Pp. 3-14. (In Russ.).

3. Brezhnev O.V. Institut zaprosa suda obshhey yurisdiktsii, arbitrazhnogo suda $v$ konstitutsionnyj (ustavnyj) sud sub"ekta Rossiyskoy Federatsii: problemy i perspektivy [Institute of the Request of the Court of General Jurisdiction, Arbitration Court to the Constitutional (Charter) Court of a Constituent Entity of the Russian Federation: Problems and Prospects]. Rossiyskaya yusticiya - Russian Justitia. 2013. Issue 10. Pp. 30-33. (In Russ.).

4. Brezhnev O.V. Razreshenie sporov o kompetentsii kak polnomochie konstitutsionnykh (ustavnykh) sudov sub"ektov Rossiyskoy Federatsii [Resolution of Disputes on Competence as a Power of Constitutional (Charter) Courts of Subjects of the Russian Federation]. Konstitutsionnoe i municipal'noe pravo - Constitutional and Municipal Law. 2015. Issue 6. Pp. 47-50. (In Russ).

5. Zor'kin V.D. Rossiya $i$ Konstitutsiya $v$ XXI veke. Vzglyad s Il'inki [Russia and the
Constitution in the $21^{\text {st }}$ Century. The view from Ilyinka]. Moscow, 2007. 400 p. (In Russ.).

6. Kazancev A. O., Savos'kin A. V. V Chelyabinskoy oblasti nezakonno uprazdnili Ustavnyj sud [The Charter Court Was Illegally Discontinued in Chelyabinsk Region]. Konstitutsionnoe i munitsipal'noe pravo - Constitutional and Municipal Law. 2014. Issue 6. Pp. 48-52. (In Russ.).

7. Kleandrov M. I. V zashhitu konstitutsionnykh (ustavnykh) sudov sub"ektov RF [In Defense of the Constitutional (Charter) Courts of Subjects of the Russian Federation]. Rossiyskaya yustitsiya - Russian Justitia. 2015. Issue 6. Pp. 2-7. (In Russ.).

8. Mazurov A. V. Kommentariy k Federal'nomu konstitutsionnomu zakonu "O Konstitutsionnom sude Rossiyskoy Federatsii” (postateynyj) [The Commentary to the Federal Constitutional Law "On the Constitutional Court of the Russian Federation" (article-by-article)]. Moscow, 2009. 576 p. (In Russ.).

9. Malyutin N.S. Ischerpan li interpretatsionnyj potentsial regional'noy konstitutsionnoy yustitsii v Rossiyskoy Federatsii? [Whether the Interpretative Potential of Regional Constitutional Justice in the Russian Federation is Exhausted]. Zhurnal konstitutsionnogo pravosudiya - Journal of Constitutional Justice. 2015. Issue 5. Pp. 13-19. (In Russ.).

10. Mikhaleva N. A. Konstitutsii i ustavy sub"ektov Rossiyskoy Federatsii (sravnitel'no-pravovoe issledovanie) [Constitutions and Statutes of the Subjects of the Russian Federation (Comparative Legal Research)]. Moscow, 2010. 366 p. (In Russ.).

11. Savos'kin A. V., Kazanzev A. O. Vozmozhno li uprazdnenie konstitutsionnogo (ustavnogo) suda sub"ekta Rossiyskoy Federatsii? [Is the Abolition of the Constitutional (Statutory) Court of the Subject of the Russian Federation Possible?]. Aktual'nye problemy rossiyskogo prava - Actual Problems of Russian Law. 2014. Issue 6. Pp. 1108-1114. (In Russ.). DOI: 10.7256/1994-1471.2014.6.11509.

12. Craig P. Constitutional and Non-constitutional Review. Current Legal Problems. 2001. Vol. 54. Issue 1. Pp. 147-178. (In Eng.). DOI: 10.1093/clp/54.1.147.

13. Dunning $W$. Essays on the Civil War and Reconstruction. New York, 1898. 376 p. (In Eng.).

14. Fino S. The Role of State Supreme Courts in the New Judicial Federalism. New York. 1987. 154 p. (In Eng.).

15. Gress F. Interstate Co-operation in the USA and the FRG. Evaluating Federal Systems; ed. by B. de Villiers. Dordrecht, 1994. Pp. 409429. (In Eng.). 
16. McWhinney E. Supreme Courts and Judicial LawMaking: Constitutional Tribunals and Constitutional Review. Dordrecht, 1986. 305 p. (In Eng).

17. Pestalozza Ch. Verfassungsprozefirecht. München, 1991. 743 p. (In Ger.).

18. Speeches and Documents of American History; ed. by R. Birley, V. London, 1962. Vol. 2. 300 p. (In Eng.).

19. The Federalist Papers by Alexander Hamilton, James Madison and John Jay. With an Introduction and Commentary by Garry Wills. New York; Toronto; London; Sydney; Auckland, 1982. 483 p. (In Eng.).

20. Vanberg G. The Politics of Constitutional Review in Germany. Cambridge, 2004. 193 p. (In Eng.). DOI: 10.1017/CBO9780511510427.

21. Weber $W$. Spannungen und Kräfte im Westdeutschen Verfassungssystem. Berlin, 1970. 375 p. (In Ger.).

22. Winkle J. W. III. Interjudicial Relations. Paper presented at the Annual Meeting of the Southern Political Science Association. Nov. 6-8. Atlanta, 1980. 320 p. (In Eng.).

\section{References in Russian}

1. Бондарь Н. С. Власть и свобода на весах конституционного правосудия. М.: ЮСТИЦИНФОРМ, 2005. 592 с.

2. Бондарь Н. С. Конституция, Конституционный Суд и налоговое право // Налоги. 2006. № 3. С. 3-14.

3. Брежнев O. В. Институт запроса суда общей юрисдикции, арбитражного суда в конституционный (уставный) суд субъекта Российской Федерации: проблемы и перспективы // Российская юстиция. 2013. № 10. С. 30-33.

4. Брежнев О. В. Разрешение споров о компетенции как полномочие конституционных (уставных) судов субъектов Российской Федерации // Конституционное и муниципальное право. 2015. № 6. С. 47-50.

5. Зорькин В.Д. Россия и Конституция в XXI веке. Взгляд с Ильинки. М.: Норма, 2007. 400 c.

6. Казанцев А. О., Савоськин А. В. В Челябинской области незаконно упразднили Уставный суд // Конституционное и муниципальное право. 2014. № 6. С. 48-52.

7. Клеандров М. И. В защиту конституционных (уставных) судов субъектов РФ // Российская юстиция. 2015. № 6. С. 2-7.
8. Мазуров A. В. Комментарий к Федеральному конституционному закону «О Конституционном Суде Российской Федерации» (постатейный). М.: Частное право, 2009. 576 с.

9. Малютин Н. С. Исчерпан ли интерпретационный потенциал региональной конституционной юстиции в Российской Федерации? // Журнал конституционного правосудия. 2015. № 5. С. 13-19.

10. Михалева Н. А. Конституции и уставы субъектов Российской Федерации (сравнительно-правовое исследование). М.: ЮРКОМПАНИ, 2010. 366 с.

11. Савоськин А. В., Казанцеев А. О. Возможно ли упразднение конституционного (уставного) суда субъекта Российской Федерации? // Актуальные проблемы российского права. 2014. № 6. С. 1108-1114.

12. Craig $P$. Constitutional and Non-constitutional Review // Current Legal Problems. 2001. Vol. 54. Iss. 1. P. 147-178.

13. Dunning $W$. Essays on the Civil War and Reconstruction. New York, 1898. 376 p.

14. Fino $S$. The Role of State Supreme Courts in the New Judicial Federalism. New York, 1987. $154 \mathrm{p}$.

15. Gress F. Interstate Co-operation in the USA and the FRG // Evaluating Federal Systems B. de Villiers (ed.). Dordrecht, 1994. Pp. 409-429.

16. McWhinney E. Supreme Courts and Judicial Law-making: Constitutional Tribunals and Constitutional Review. Dordrecht, 1986. 305 p.

17. Pestalozza Ch. Verfassungsprozefirecht. München, 1991. $743 \mathrm{~s}$.

18. Speeches and Documents of American History / ed. by R. Birley, V. London, 1962. Vol. 2. $300 \mathrm{p}$.

19. The Federalist Papers by Alexander Hamilton, James Madison and John Jay. With an Introduction and Commentary by Garry Wills. New York; Toronto; London; Sydney; Auckland, 1982. $483 \mathrm{~s}$.

20. Vanberg G. The Politics of Constitutional Review in Germany. Cambridge, 2004. 193 p.

21. Weber $W$. Spannungen und Kräfte im Westdeutschen Verfassungssystem. Berlin, $1970.375 \mathrm{p}$.

23. Winkle J. W. III. Interjudicial Relations. Paper presented at the Annual Meeting of the Southern Political Science Association. Nov. 6-8. Atlanta, 1980. 320 p. 